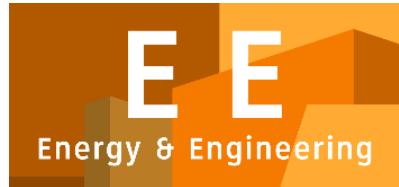

PAPER - OPEN ACCESS

\title{
Kajian Peleburan Dan Pembekuan Material Berubah Phasa Pada Thermal Storage
}

\author{
Author \\ : Chandra A Siregar \\ DOI \\ : 10.32734/ee.v1i1.122 \\ ISSN \\ : 2654-7031 \\ E-ISSN \\ : 2654-704X
}

Volume 1 Issue 1 - 2018 TALENTA Conference Series: Energy and Engineering

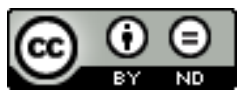

This work is licensed under a Creative Commons Attribution-NoDerivatives 4.0 International License.

Published under licence by TALENTA Publisher, Universitas Sumatera Utara
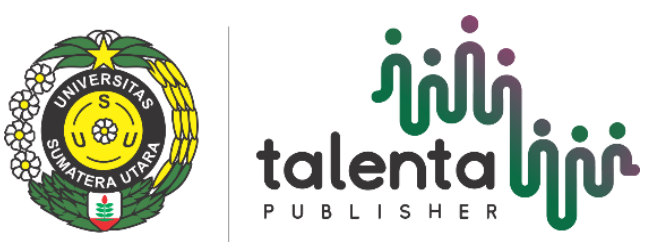


\title{
jiji talentalioio TALENTA Conference Series \\ P U B L I S H E R Available online at https://talentaconfseries.usu.ac.id \\ Energy \& Engineering \\ Kajian Peleburan Dan Pembekuan Material Berubah Phasa Pada Thermal Storage
}

\author{
Chandra A Siregar ${ }^{a *}$, Ilmi Abdullah ${ }^{\mathrm{b}}$, Himsar Ambarita $^{\mathrm{c}}$ \\ ${ }^{a}$ Fakultas Teknik, Universitas Sumatera Utara, Medan \\ ${ }^{b}$ Magister Teknik Mesin, Universitas Sumatera Utara, Medan \\ ${ }^{c}$ Pusat Riset Sustanable Energy, Universitas Sumatera Utara, Medan \\ ndra_mei86@yahoo.co.id
}

\begin{abstract}
Abstrak
Kajian fenomena peleburan dan pemadatan material berubah phasa (Phasa Change Material/PCM) dilakukan untuk mengamati proses peleburan dari Paraffin Wax dan Stearic Acid. Percobaan dilakukan pada temperatur $90{ }^{\circ} \mathrm{C}, 85{ }^{\circ} \mathrm{C}$, dan $80{ }^{\circ} \mathrm{C}$ dengan menggunakan kotak kaca dan durasi waktu peleburan 600 menit. Pengamatan visualisasi dilakukan dalam bentuk foto. Hasil pengamatan visualisasi menyatakan bahwa temperatur Thermal Energy Storage (TES) yang lebih tinggi bergerak keatas. Oleh karena itu, proses peleburan terlebih dahulu terjadi pada bagian atas. Selain itu, dalam proses pembekuan TES dimulai dari bagian bawah menuju ke atas. Dari hasil penelitian ditemukan bahwa Paraffin Wax lebih efektif digunakan daripada Stearic Acid karena mampu menyerap panas lebih tinggi. Pada temperatur pengujian $90{ }^{\circ} \mathrm{C}$ diperoleh nilai panas tersimpan pada Paraffin sebesar 61,84 kJ sedangkan pada Stearic Acid 57,392 kJ.
\end{abstract}

Kata Kunci: Thermal Energy Storage; peleburan dan pembekuan;

\section{Pendahuluan}

Indonesia merupakan Negara tropis yang mendapat sinar atau radiasi matahari dengan intensitas cukup tinggi. Intensitas radiasi matahari yang sampai ke bumi dapat dimanfaatkan sebagai penyedia energi alternatif dan berkesinambungan dan tidak habis (renewable energy). Pemanfaatan energi matahari tersebut dapat dilakukan dengan konversi panas dan konversi pembangkit listrik tenaga surya (fotovoltaik).

Jaisankar, dkk [1] menyebutkan Pemanfaatan energi matahari melalui konversi panas jauh lebih efisien daripada dengan menggunakan tekonologi fotovoltaik. Sistem fotovoltaik hanya memiliki efisiensi sekitar 17\%, sedangkan efisiensi konversi panas matahari dapat mencapai sekitar $70 \%$.

Salah satu penggunaanya pada aplikasi pemanas air tenaga matahari (Solar Water Heater). Namun pada prakteknya pemanas air membutuhkan sumber energi energi tambahan yakni energi listrik untuk menjaga konsistensi temperatur air. Rekayasa teknologi terus dikembangkan untuk mengatasi masalah tersebut. Salah satunya dengan melakukan penambahan material penyimpanan panas (Thermal Energy Storage/TES).

TES merupakan material berubah phasa (Phasa Change Material/PCM) yang dapat melebur dan membeku. S.A Khot,dkk [2] mengungkapkan PCM merupakan suatu zat dengan kapasitas penyimpanan panas laten yang tinggi, melebur dan padat pada suhu tertentu. Memiliki kemampuan menyimpan dan melepaskan energi. PCM dianggap mampu untuk menyerap panas. Kriteria konduksi dan konveksi perpindahan panas memungkinkan PCM untuk menyimpan panas ini sebagai panas laten. 
Material ini dianggap merupakan sebuah solusi untuk mengganti peran energi listrik pada aplikasi Solar Water Heater sehingga dapat mengatasi/mengurangi penggunaan energi listrik. Hal ini seusia sesuai dengan kebijakan pemerintah Republik Indonesia terkait kebijakan penghematan energi nasional sehingga subsidi BBM dan Listrik dapat dikurangi.

Mettawe, dkk [3] menyatakan lilin (paraffin wax) merupakan salah satu jenis PCM yang berfungsi sebagai penyimpanan panas laten pada pemanas air tenaga surya. Hasil percobaan dengan penerapan kolektor surya untuk pemanas air menunjukan proses penyerapan energi matahari, koefisien perpindahan panas rata-rata meningkat dengan meningkatnya ketebalan lapisan cairan lilin.

Dalam penelitian ini diberikan pembatasan masalah terkait PCM yang akan digunakan yakni Paraffin Wax dan Stearic Acid. Sehingga dapat memberikan informasi terkait fenomena/proses peleburan dan karakteristik parrafin wax, stearic acid pada saat berubah fasa dari cair ke padat dan dari padat ke cair. Selain itu, juga untuk mengkonfirmasi kesesuaian parrafin wax, stearic acid dalam meningkatkan kinerja termal serta memberikan informasi terkait analisis kecepatan penyerapan dan pelepasan panas dari dua jenis PCM yakni parrafin wax, stearic acid.

\section{Metode Penelitian}

\subsection{Rancangan Alat Uji}

Pada penelitian ini, material PCM yang digunakan adalah Paraffin Wax dan Stearic Acid . Pengujian dilakukan pada tiga temperatur yang berbeda yakni pada 90 oC, 85 oC dan 80 oC. PCM yang akan diuji masing-masing $0,8 \mathrm{Kg}$. Sebagai tempat alat uji digunakan wadah berbahan kaca guna memudahkan melakukan pengamatan peleburan dan pembekuan. Wadah berbentuk persegi panjang dengan ukuran $300 \mathrm{~mm}$ x $100 \mathrm{~mm}$ x $100 \mathrm{~mm}$ yang terbagi dalam tiga bagian dan dibatasi/disekat oleh sebuah plat alumanium dengan tebal $2 \mathrm{~mm}$ dan dimensi $100 \mathrm{~mm}$ x $100 \mathrm{~mm}$. Menurut C.A. Bauer, dkk [5] penambahan plat alumanium dilakukan dengan tujuan untuk meningkatkan laju perpindahan panas dari sumber panas ke PCM.

Pada bagian kotak I, air akan dipanaskan dengan menggunakan alat pemanas air (heater) yang dilengkapi dengan sistem kontrol temperatur. Air panas tersebut akan mentransferkan panas ke bagian II yang didalamnya terdapat material uji. Sehingga material uji akan berubah phasa nya dari phasa padat ke cair (melting).

Pada bagian kotak II diberikan termokopel sebanyak 9 titik yang terhubung dengan agilent yang berfungsi untuk merekam data-data temperatur per menit. Penempatan titik - titik termokopel tersebut ditampilkan pada tabel 1 dibawah ini. Sedangkan pada kotak III hanya diisi air pada temperatur lingkungan (27 - 28 0C) dan tidak diberikan sumber panas lain.

Tabel 1. Koordinat penempatan titik-titik termokopel

\begin{tabular}{|c|c|c|c|c|}
\hline No & Termokopel & $\mathrm{X}(\mathrm{mm})$ & sumbu koordinat $\mathrm{Y}(\mathrm{mm})$ & $\mathrm{Z}(\mathrm{mm})$ \\
\hline 1 & $\mathrm{~T} 1$ & 25 & 25 & 25 \\
\hline 2 & $\mathrm{~T} 2$ & 50 & 25 & 25 \\
\hline 3 & $\mathrm{~T} 3$ & 75 & 25 & 25 \\
\hline 4 & $\mathrm{~T} 4$ & 25 & 50 & 50 \\
\hline 5 & T5 & 50 & 50 & 50 \\
\hline 6 & T6 & 75 & 50 & 50 \\
\hline 7 & $\mathrm{~T} 7$ & 25 & 75 & 75 \\
\hline 8 & $\mathrm{~T} 8$ & 50 & 75 & 75 \\
\hline 9 & T9 & 75 & 75 & 75 \\
\hline
\end{tabular}

Pengamatan secara visual berupa foto dan video dilakukan dengan menggunakan kamera. Pengujian yang dilakukan akan memberikan informasi terkait analisis kecepatan penyerapan dan pelepasan panas dari kedua jenis PCM yang digunakan. Secara umum, rancangan alat penelitian ditampilkan pada gambar 1 dibawah ini. 


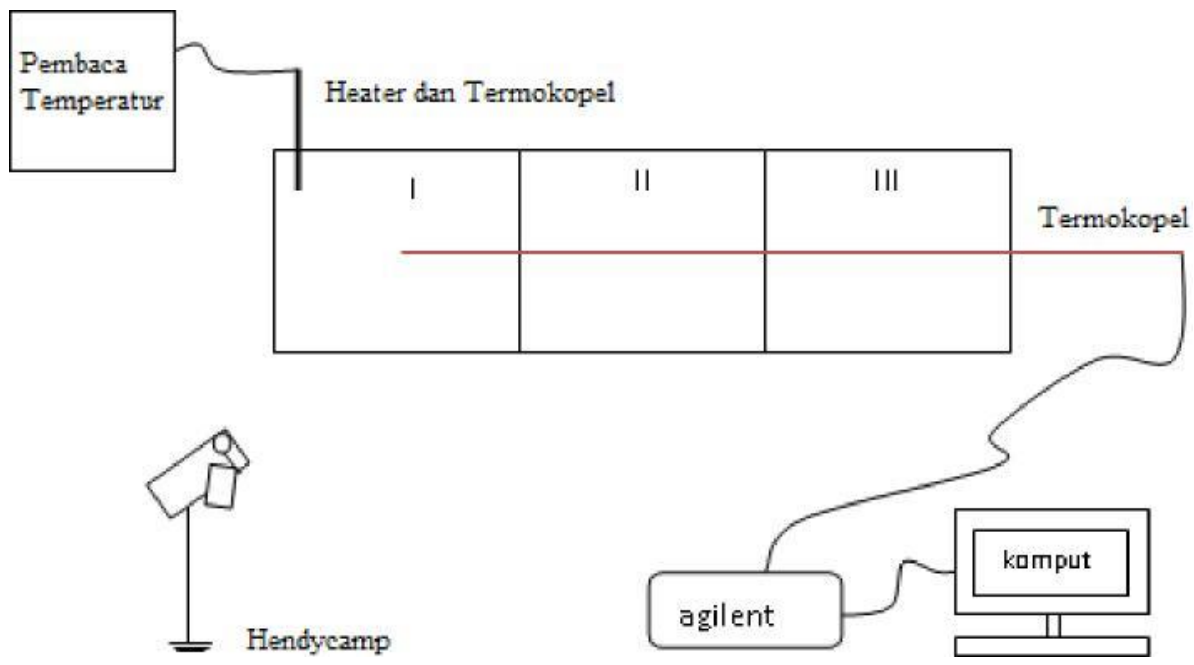

Gambar 1. Susunan Wadah kaca sebagai tempat alat uji.

Tabel 2. Sifat-sifat termophysical material berubah phasa yang digunakanan dalam penelitian.

\begin{tabular}{lll}
\hline Sifat-sifat & $\begin{array}{l}\text { Paraffin wax } \\
\text { (S.A Khot, 2011) }\end{array}$ & $\begin{array}{l}\text { Stearic acid } \\
\text { (Sharma, 2009) }\end{array}$ \\
\hline Melting temperature $\left({ }^{\circ} \mathrm{C}\right)$ & 59,8 & 55,1 \\
Latent heat of fusion $(\mathrm{kJ} / \mathrm{kg})$ & 190 & 160 \\
Density $\left(\mathrm{kg} / \mathrm{m}^{3}\right)$ & & 965 \\
Solid & 910 & 848 \\
Liquid & 790 & \\
Specific heat $\left(\mathrm{kJ} /\left(\mathrm{kg} \cdot{ }^{\circ} \mathrm{C}\right)\right.$ & & 1,6 \\
Solid & 2,0 & 2,2 \\
Liquid & 2,15 & \\
Thermal conductivity $(\mathrm{W} / \mathrm{m} \cdot \mathrm{K})$ & & $0,36($ Heri, 2012) \\
Solid & 0,24 & 0,172 \\
Liquid & 0,22 &
\end{tabular}

\subsection{Prinsip Kerja}

Pada kotak kaca I diberikan pemanas dengan kapasitas Daya 500 Watt (pabrikan) dan Tegangan 220 volt, pemanas tersebut rangkaikan dengan satu unit termokopel yang berfungsi untuk menjaga dan mengatur temperatur. Sebagai contoh, pada pengujian $90^{\circ} \mathrm{C}$ pemanas akan berhenti berfungsi apabila termokopel sudah menunjukan temperatur 92 ${ }^{\circ} \mathrm{C}$ dan akan kembali berfungsi pada temperatur $88{ }^{\circ} \mathrm{C}$. Prinsip yang sama juga akan terjadi pada pengujian $85{ }^{\circ} \mathrm{C}$ dan $80{ }^{\circ} \mathrm{C}$.

Kotak pertama akan mengairkan panas ke kotak kedua melalui dinding alumanium karena pada prinsipnya panas dapat berpindah dari suatu tempat ke tempat yang lain atau dari suatu benda ke benda yang lain atau dari suatu zat ke zat yang lain karena adanya perbedaan temperatur. Dengan kata lain, panas hanya akan berpindah dari suatu benda ke benda yang lain jika terdapat perbedaan temperatur antara dua benda tersebut. Panas akan berpindah dari temperatur yang lebih tinggi ke temperatur yang lebih rendah [7]. 
Latent heat storage (LHS) atau penyimpanan panas laten didasarkan pada penyerapan panas ketika bahan penyimpanan mengalami perubahan fase dari padat ke cair atau cair ke cair. Jumlah panas yang dibutuhkan untuk mengubah material dari satu fasa ke fasa lainnya dirumuskan sebagai berikut:

$$
Q_{c}=m \cdot a_{m} \cdot \Delta h_{m}
$$

Laju perpindahan panas konduksi dapat dinyatakan dengan Hukum Fourier [8]. Laju perpindahan panas secara konduksi dan konveksi dirumuskan dalam persamaan 2 dan 3 sebagai berikut:

$$
\begin{aligned}
& q=-k A \frac{d T}{d x} \\
& Q_{\text {konv }}=h A_{s}\left(T_{s}-T_{\infty}\right)
\end{aligned}
$$

Nilai koefisien konveksi dapat dihitung berdasarkan persamaan berikut ini:

$$
h=\frac{N_{u} k}{L}
$$

Jumlah panas yang tersimpan dapat dirumuskan sebagai berikut

$$
q m=m \cdot c p \cdot(T f-T i)
$$

\section{Hasil dan Pembahasan}

Pada paper ini yang akan ditampilkan hanya hasil pengujian pada temperatur $90{ }^{\circ} \mathrm{C}$ dengan durasi waktu 600 menit. Pengukuran temperatur untuk melihat laju perpindahan panas dilakukan dengan 9 titik pengukuran.

Tabel 3: Hasil pengukuran temperatur Paraffin Wax per 60 menit pada proses peleburan pada temperatur $90{ }^{\circ} \mathrm{C}$

\begin{tabular}{lllllllllll}
\hline No & \multicolumn{3}{c}{ Waktu (menit) } & \multicolumn{2}{c}{ Temperatur $\left({ }^{0} \mathrm{C}\right)$} & & & & \\
& & $\mathrm{T} 1$ & $\mathrm{~T} 2$ & $\mathrm{~T} 3$ & $\mathrm{~T} 4$ & $\mathrm{~T} 5$ & $\mathrm{~T} 6$ & $\mathrm{~T} 7$ & $\mathrm{~T} 8$ & $\mathrm{~T} 9$ \\
\hline 1 & 1 & 26,879 & 26,994 & 26,954 & 26,865 & 26,996 & 26,776 & 26,876 & 26,876 & 26,887 \\
2 & 60 & 64,545 & 47,332 & 32,186 & 47,501 & 40,234 & 35,756 & 42,079 & 42,079 & 29,753 \\
3 & 120 & 65,521 & 64,464 & 40,314 & 63,75 & 54,486 & 46,547 & 55,58 & 55,58 & 32,45 \\
4 & 180 & 65,45 & 64,873 & 50,239 & 63,255 & 62,344 & 60,972 & 59,737 & 59,737 & 36,216 \\
5 & 240 & 66,779 & 65,775 & 59,243 & 63,623 & 63,376 & 63,301 & 60,124 & 60,124 & 40,606 \\
6 & 300 & 66,616 & 66,766 & 63,86 & 65,017 & 64,835 & 64,696 & 60,519 & 60,519 & 48,074 \\
7 & 360 & 66,717 & 66,827 & 65,237 & 66,195 & 66,075 & 65,902 & 60,993 & 60,993 & 62,236 \\
8 & 420 & 66,845 & 66,943 & 65,491 & 66,286 & 66,119 & 66,05 & 61,192 & 61,192 & 62,244 \\
9 & 480 & 67,953 & 67,342 & 65,545 & 66,193 & 66,093 & 65,948 & 61,649 & 61,649 & 62,456 \\
10 & 540 & 67,118 & 67,725 & 65,89 & 66,595 & 66,459 & 66,355 & 62,184 & 62,184 & 62,567 \\
11 & 600 & 68,889 & 67,667 & 66,636 & 66,833 & 66,541 & 66,669 & 62,544 & 62,488 & 62,628 \\
\hline
\end{tabular}


Tabel 4: Hasil pengukuran temperatur Stearic Acid per 60 menit pada proses peleburan pada temperatur $90{ }^{\circ} \mathrm{C}$

\begin{tabular}{|c|c|c|c|c|c|c|c|c|c|c|}
\hline \multirow{2}{*}{ No } & \multirow{2}{*}{ Waktu } & \multicolumn{9}{|c|}{ TERMOKOPEL } \\
\hline & & $\overline{\mathrm{T} 1}$ & $\mathrm{~T} 2$ & T3 & $\mathrm{T} 4$ & T5 & T6 & $\mathrm{T} 7$ & T8 & T9 \\
\hline$\overline{1}$ & 0 & 25,467 & 25,177 & 25,159 & 25,246 & 25,252 & 25,229 & 25,235 & 25,293 & 25,217 \\
\hline 2 & 60 & 58,218 & 33,456 & 29,367 & 48,161 & 41,182 & 31,382 & 50,792 & 36,557 & 28,634 \\
\hline 3 & 120 & 64,355 & 64,124 & 46,618 & 62,351 & 49,161 & 43,12 & 61,295 & 62,887 & 56,403 \\
\hline 4 & 180 & 64,119 & 63,699 & 62,98 & 61,74 & 59,709 & 53,034 & 60,634 & 61,377 & 56,832 \\
\hline 5 & 240 & 64,793 & 64,476 & 63,94 & 62,046 & 62,076 & 62,356 & 60,86 & 61,886 & 57,134 \\
\hline 6 & 300 & 64,793 & 64,544 & 64,154 & 62,27 & 62,31 & 62,884 & 60,964 & 62,194 & 57,489 \\
\hline 7 & 360 & 64,826 & 64,482 & 64,039 & 62,369 & 62,403 & 62,894 & 61,073 & 62,201 & 57,812 \\
\hline 8 & 420 & 65,317 & 65,163 & 64,737 & 62,745 & 62,818 & 63,47 & 61,399 & 62,708 & 58,358 \\
\hline 9 & 480 & 65,59 & 65,243 & 64,652 & 62,681 & 62,708 & 63,207 & 61,36 & 62,522 & 58,552 \\
\hline 10 & 540 & 65,321 & 65,085 & 64,734 & 62,812 & 62,859 & 63,352 & 61,459 & 62,665 & 58,943 \\
\hline 11 & 600 & 64,947 & 64,7 & 64,296 & 62,564 & 62,631 & 63,143 & 61,306 & 62,448 & 59,202 \\
\hline
\end{tabular}

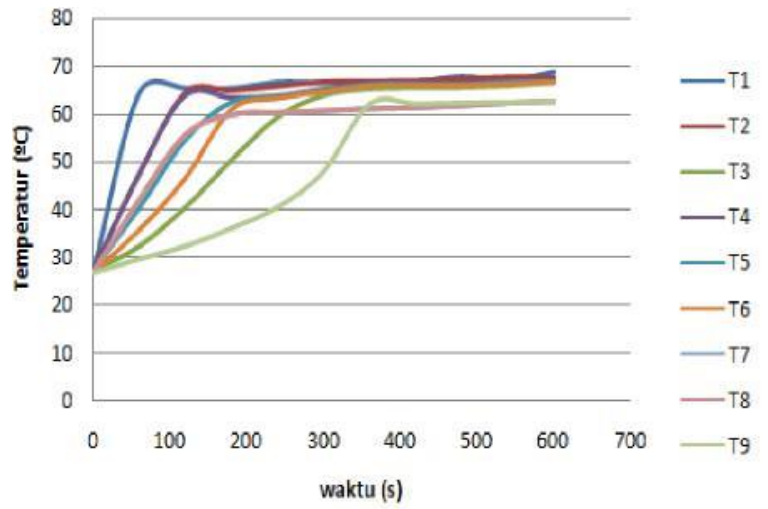

(a)

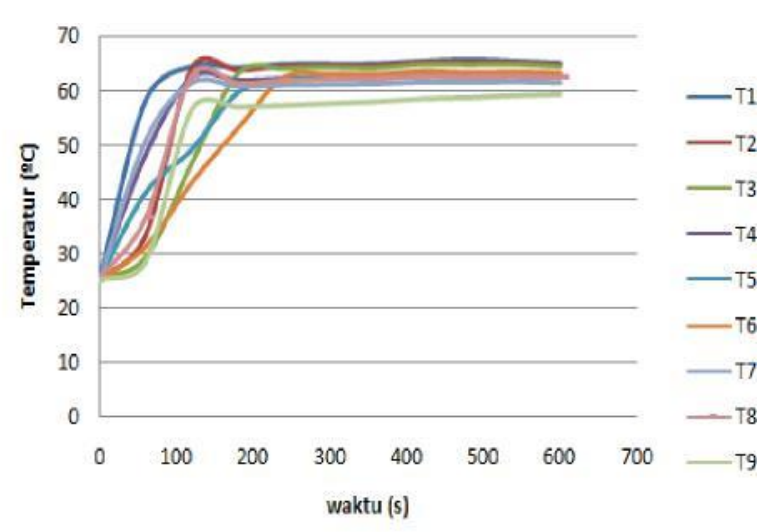

(b)

Gambar 2. Grafik hubungan temperatur pada pengujian peleburan dengan waktu pada Paraffin Wax (a) dan Stearic Acid (b) pada pengujian peleburan temperatur $90^{\circ} \mathrm{C}$.

Dengan demikian diperoleh temperatur tertinggi rata-rata yakni pada pengujian temperatur $90{ }^{\circ} \mathrm{C}$, Paraffin Wax memiliki temperatur rata-rata $65,655^{\circ} \mathrm{C}$ sedangkan pada Stearic Acid $62,82{ }^{\circ} \mathrm{C}$. Pada pengujian dengan temperatur 85 ${ }^{0} \mathrm{C}$, Paraffin Wax memiliki temperatur rata-rata $64,24{ }^{\circ} \mathrm{C}$ sedangkan pada Stearic Acid $62,29{ }^{\circ} \mathrm{C}$. Pada pengujian dengan temperatur $80{ }^{\circ} \mathrm{C}$, Paraffin Wax memiliki temperatur rata - rata $62,54{ }^{\circ} \mathrm{C}$, sedangkan pada Stearic Acid 57,10 ${ }^{0} \mathrm{C}$. 
Tabel. 5. Hasil pengukuran temperatur Paraffin Wax per 60 menit pada proses pembekuan dari temperatur pengujian $900 \mathrm{C}$

\begin{tabular}{|c|c|c|c|c|c|c|c|c|c|c|}
\hline \multirow{2}{*}{ No } & \multirow{2}{*}{ Waktu (menit) } & \multicolumn{9}{|c|}{ TERMOKOPEL } \\
\hline & & $\mathrm{T} 1$ & $\mathrm{~T} 2$ & $\mathrm{~T} 3$ & $\mathrm{~T} 4$ & $\mathrm{~T} 5$ & T6 & $\mathrm{T} 7$ & $\mathrm{~T} 8$ & T9 \\
\hline 1 & 0 & 68,889 & 67,667 & 66,636 & 66,833 & 66,541 & 66,669 & 62,544 & 62,488 & 62,628 \\
\hline 2 & 60 & 50,848 & 52,918 & 55,397 & 55,254 & 55,154 & 55,17 & 55,011 & 54,208 & 51,008 \\
\hline 3 & 120 & 45,534 & 46,469 & 54,258 & 54,344 & 53,904 & 54,116 & 53,028 & 52,667 & 46,733 \\
\hline 4 & 180 & 40,669 & 41,463 & 52,123 & 52,753 & 51,724 & 52,429 & 49,207 & 50,007 & 43,569 \\
\hline 5 & 240 & 37,528 & 38,13 & 48,548 & 49,291 & 48,76 & 49,375 & 44,919 & 47,99 & 40,36 \\
\hline 6 & 300 & 35,357 & 35,766 & 44,357 & 44,982 & 46,101 & 45,736 & 41,082 & 44,968 & 37,951 \\
\hline 7 & 360 & 33,919 & 34,258 & 40,769 & 41,242 & 42,383 & 42,026 & 38,286 & 40,124 & 35,819 \\
\hline 8 & 420 & 33,548 & 34,122 & 38,298 & 38,444 & 39,323 & 39,052 & 36,417 & 37,984 & 34,72 \\
\hline 9 & 480 & 33,437 & 33,812 & 36,591 & 36,663 & 37,148 & 37,046 & 35,003 & 36,012 & 33,86 \\
\hline 10 & 540 & 32,872 & 33,114 & 35,005 & 35,071 & 35,342 & 35,293 & 33,779 & 34,651 & 32,948 \\
\hline 11 & 600 & 32,284 & 32,525 & 33,812 & 33,837 & 33,985 & 33,889 & 32,861 & 33,667 & 32,153 \\
\hline 12 & 660 & 31,756 & 32,069 & 33,059 & 32,963 & 33,046 & 33,006 & 32,27 & 32,932 & 31,643 \\
\hline 13 & 720 & 31,502 & 31,689 & 32,363 & 32,364 & 32,417 & 32,279 & 31,712 & 32,237 & 31,053 \\
\hline 14 & 780 & 31,242 & 31,432 & 31,973 & 31,895 & 31,876 & 31,889 & 31,316 & 31,567 & 30,843 \\
\hline 15 & 840 & 30,638 & 30,685 & 31,265 & 31,293 & 31,256 & 31,233 & 30,824 & 30,913 & 30,258 \\
\hline 16 & 900 & 28,968 & 28,936 & 29,579 & 29,643 & 29,63 & 29,332 & 30,712 & 30,667 & 30,342 \\
\hline 17 & 960 & 27,288 & 27,196 & 27,869 & 27,933 & 27,974 & 27,43 & 27,872 & 27,781 & 27,621 \\
\hline
\end{tabular}

Tabel. 6: Hasil pengukuran temperatur Stearic Acid per 60 menit pada proses pembekuan dari temperatur pengujian $90{ }^{\circ} \mathrm{C}$

\begin{tabular}{|c|c|c|c|c|c|c|c|c|c|c|}
\hline \multirow{2}{*}{ No } & \multirow{2}{*}{$\begin{array}{l}\text { Waktu } \\
\text { (Menit) }\end{array}$} & \multicolumn{9}{|c|}{ TERMOKOPEL $\left({ }^{\circ} \mathrm{C}\right)$} \\
\hline & & $\mathrm{T} 1$ & $\mathrm{~T} 2$ & $\mathrm{~T} 3$ & $\mathrm{~T} 4$ & T5 & T6 & $\mathrm{T} 7$ & $\mathrm{~T} 8$ & T9 \\
\hline 1 & 0 & 64,947 & 64,7 & 64,296 & 62,564 & 62,631 & 63,143 & 61,306 & 62,448 & 59,402 \\
\hline 2 & 60 & 60,339 & 60,431 & 60,493 & 60,062 & 60,159 & 60,388 & 59,032 & 57,634 & 57,249 \\
\hline 3 & 120 & 51,421 & 51,771 & 51,847 & 52,56 & 52,479 & 52,395 & 52,153 & 52,053 & 51,796 \\
\hline 4 & 180 & 50,674 & 50,037 & 49,881 & 52,566 & 52,474 & 52,39 & 51,491 & 52,21 & 51,934 \\
\hline 5 & 240 & 48,359 & 47,61 & 47,993 & 52,147 & 52,254 & 51,911 & 46,629 & 52,135 & 51,239 \\
\hline 6 & 300 & 44,428 & 44,561 & 44,412 & 50,656 & 52,065 & 49,701 & 42,441 & 45,91 & 46,988 \\
\hline 7 & 360 & 39,975 & 40,738 & 40,874 & 46,821 & 47,983 & 45,204 & 39,397 & 39,772 & 42,637 \\
\hline 8 & 420 & 37,638 & 37,991 & 37,345 & 43,377 & 43,891 & 41,924 & 37,12 & 37,456 & 39,372 \\
\hline 9 & 480 & 35,145 & 36,325 & 32,403 & 39,633 & 38,098 & 38,009 & 34,801 & 36,98 & 36,357 \\
\hline 10 & 540 & 33,074 & 33,094 & 31,469 & 35,589 & 34,987 & 35,012 & 32,893 & 34,091 & 33,616 \\
\hline 11 & 600 & 31,908 & 31,892 & 31,286 & 32,738 & 33,324 & 33,987 & 31,629 & 32,479 & 31,747 \\
\hline 12 & 660 & 30,301 & 30,547 & 30,67 & 30,761 & 31,891 & 31,761 & 31,098 & 31,342 & 31,542 \\
\hline 13 & 720 & 29,984 & 29,123 & 29,879 & 29,345 & 29,341 & 30,124 & 30,435 & 30,536 & 30,871 \\
\hline 14 & 780 & 29,342 & 28,98 & 29,098 & 28,769 & 28,674 & 29,561 & 29,563 & 29,412 & 29,563 \\
\hline 15 & 840 & 28,78 & 28,091 & 28,567 & 28,067 & 28,12 & 28,967 & 28,761 & 28,901 & 28,976 \\
\hline 16 & 900 & 28,102 & 27,98 & 28,032 & 27,943 & 27,934 & 28,032 & 28,036 & 28,121 & 28,034 \\
\hline 17 & 960 & 27,56 & 27,312 & 27,651 & 27,329 & 27,564 & 27,671 & 27,783 & 27,732 & 27,56 \\
\hline
\end{tabular}




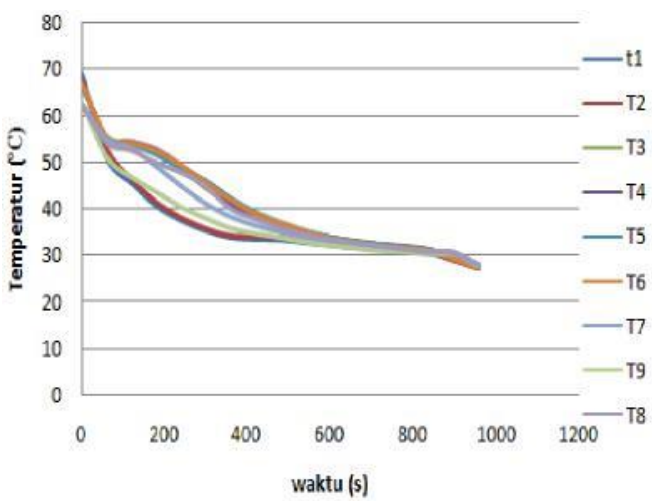

(a)

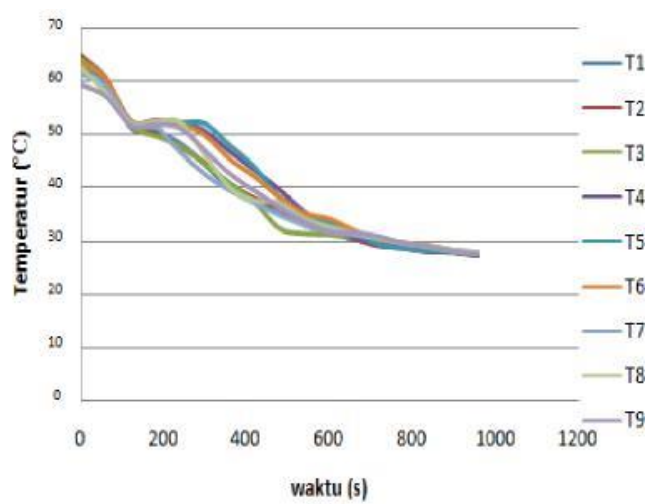

(b)

Gambar 4. Grafik hubungan temperatur pada pengujian pembekuan dengan waktu pada Paraffin Wax (a) dan Stearic Acid (b) dari temperatur pengujian temperatur $90{ }^{\circ} \mathrm{C}$.

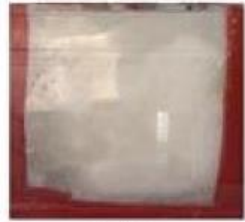

OMenit

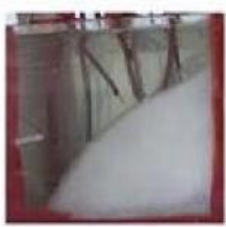

180 Ment

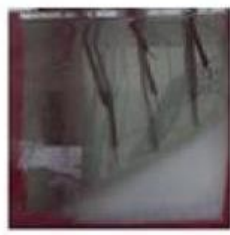

360 Menit

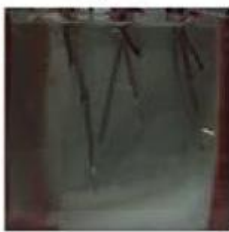

540 Meni:

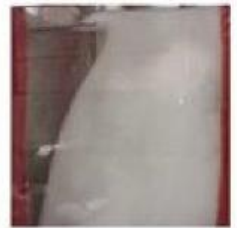

60 Menit

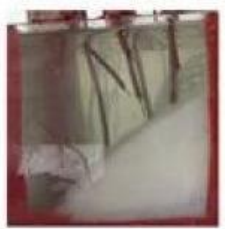

240 Ment

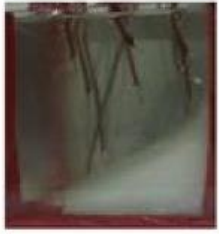

420 Ment

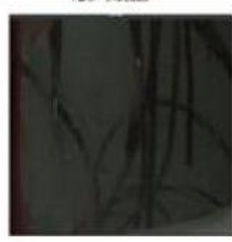

600 Menit

(a)

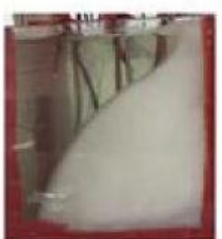

120 Menit

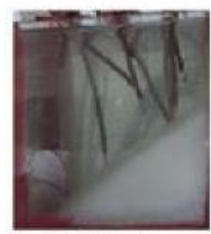

300 Merit

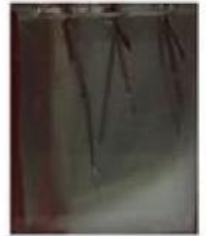

480 Ment

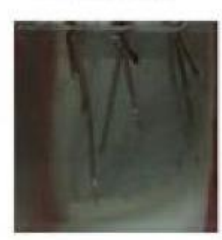

540 menit

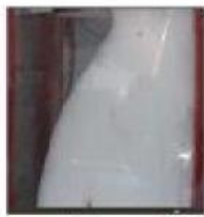

60 menit

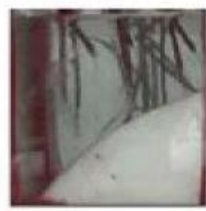

180 menit
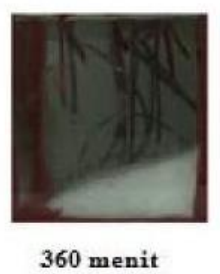

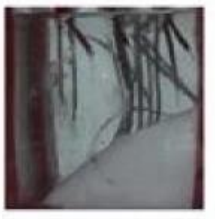

240 menit

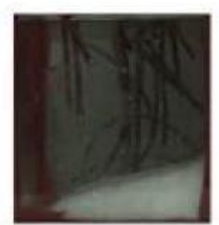

420 menit

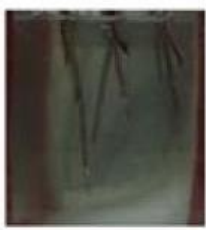

600 menit

(b)

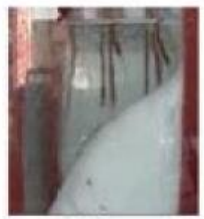

120 menit

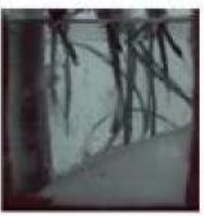

300 menit

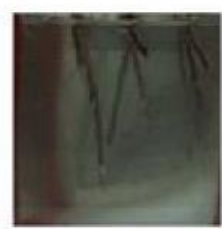

480 menit

Gambar 5. Bentuk - bentuk visualisasi peleburan Paraffin Wax (a) dan Stearic Acid (b) setiap 60 menit.

Hasil perhitungan jumlah panas tersimpan pada setiap pengujian ditampilkan pada tabel 7 dibawah ini. 
Tabel 7. Hasil perhitungan jumlah panas tersimpan

\begin{tabular}{lllllll}
\hline & $\begin{array}{l}\mathrm{T} \\
\text { Material }\end{array}$ & Pegujian & & & & \\
\hline$\left.{ }^{\circ} \mathrm{C}\right)$ & $\mathrm{m}(\mathrm{kg})$ & $\mathrm{cp}\left(\mathrm{kJ} / \mathrm{Kg}{ }^{\circ} \mathrm{C}\right)$ & $\mathrm{Tf}\left({ }^{\circ} \mathrm{C}\right)$ & $\mathrm{Ti}\left({ }^{\circ} \mathrm{C}\right)$ & $\mathrm{qm}(\mathrm{kj})$ \\
\hline Paraffix Wax & 90 & 0,8 & 2 & 65,65 & 27 & 61,84 \\
Paraffix Wax & 85 & 0,8 & 2 & 62,87 & 27 & 57,392 \\
Paraffix Wax & 80 & 0,8 & 2 & 60,63 & 27 & 53,808 \\
Stearic Acid & 90 & 0,8 & 1,6 & 63,101 & 27 & 46,20928 \\
Stearic Acid & 85 & 0,8 & 1,6 & 58,15 & 27 & 39,872 \\
Stearic Acid & 80 & 0,8 & 1,6 & 57,753 & 27 & 39,36384 \\
\hline
\end{tabular}

\section{Kesimpulan}

Dari percobaan yang dilakukan dapat disimpulkan bawah Paraffin Wax memiliki efektifitas penyerapan panas yang lebih tinggi daripada Stearic Acid. Hal ini juga sejalan dengan temperatur hasil pengukuran, diperoleh bahwa temperatur tertinggi dimiliki oleh Paraffin Wax. Selain itu, Paraffin Wax juga memiliki kemampuan dalam penyimpanan panas yang lebih baik daripada Stearic Acid. Sehingga dapat diberikan rekomendasi bahwa Paraffin Wax lebih baik digunakan daripada Stearic Acid sebagai material penyimpan panas. Pada proses peleburan dan pembekuan, kedua material ini memiliki kesamaan yakni peleburan dimulai dari sumber panas kemudian mengalir ke bagian atas lalu ke bagian bawah. Pada pembekuan dimulai dari bagian bawah bergerak ke bagian atas.

\section{Daftar Pustaka}

[1] Jaisankar S., Ananth J., Thulasi S. Jayasuthakar S.T., and Sheeba, K.N. (2011). Comprehensive Review On Solar Water Heaters. Renewable and Sustainable Energy Reviews (Elsevier), 15 (2011) 3045- 3050.

[2] Khot S.A., Sane N.K., and Gawali B.S. (2011). Experimental Investigation of Phase Change Phenomena of Paraffin Wax inside a Capsule. International Journal of Engineering Trends and Technology-Volume 2 Issue 2 (2011) ISSN 2231-5381.

[3] Mettawee. Eman Bellah S., Assassa. Ghazy M.R. (2006). Experimental study of a compact PCM solarcollector. Energi (elsevier) 31 (2006) 2958-2968.

[4] Liputan6.com. (2012). Presiden Umumkan Lima Kebijakan Penghematan Energi. http://www.liputan6.com/globe/406508/. Diakses tanggal 06 Juni 2012.

[5] C.A. Bauer, R.A. Wirtz, (2000). Thermal characteristics of a compact, passive thermal energy storage device. Proceedings of the 2000 ASME IMECE, Orlando (Florida, USA).

[6] Sharma, A., Chen, C.R., Murty V.V.S., and Sukla, A. (2009). Solar Cooker With Latent Heat Storage System : A Review. Renewable and Sustanable Energy Reviews. Elsevier vol 13 (2009) 1559 - 1605

[7] Duffie, Jhon A. and Beckman, William. A. (2006) Solar Engineering of Thermal Processes, first edition, Jhon Wiley \& Sons Inc., New York.,

[8] Cengel, A. Yunus. (2002). Heat Transfer. E-book Eddition. 